\title{
Memorandum on French Bishops during the Occupation of France (1940-44)
}

\author{
Henri de Lubac, S.J. $(\dagger)$
}

The French Jesuit Henri de Lubac (1896-1991) became one of the Catholic Church's major theologians and he exercised significant influence on the documents of Vatican Council II (1962-65). Earlier, he had been forbidden to teach due to some of his ideas (from 1950 to 1958) but came to be honored by Pope John Paul II (r.1978-2005) with an appointment to the College of Cardinals in 1983. He had been one of the founders of Sources chrétiennes (Christian sources), which published critical editions of the church fathers and, thus, promoted patristics as a major field of Christian theology. De Lubac was in the resistance to the Nazis during the occupation of France and, as the memorandum indicates, he also became a strong critic of the French Catholic Church's leadership during that period. De Lubac wrote this 1944 memorandum, published here for the first time in English translation, for his friend Jacques Maritain (1882-1973) who had been named the French ambassador to the Vatican where he served until 1948. De Lubac was a member of the 1946 Jesuit general congregation that abrogated the decree prohibiting the admission of candidates of Jewish ancestry to the Society of Jesus.

The person writing these notes does not intend them to be a complete rendering of what today is called "the matter of the bishops"; he has neither the time, nor the desire. It is an issue that is as thorny from a legal point of view as it is painful for the Catholic conscience. The writer only wishes to briefly mention a few points and only decided to do so because of a high-level request made, which he could not refuse, despite his wishes. Besides having no documentation at his disposal (the person who will be responsible for the difficult task of gathering it will find it more than abundant!), his intention is less to record the facts than to indicate a state of mind and what he cites will be for

* Published with permission from Revue des deux mondes, where it first appeared in February 1992 as "La question des évêques sous l'occupation." Translated by Ms. Andréa Javel, senior lecturer in the Romance Languages Department at Boston College and edited by James Bernauer.

(C) LUBAC, 2018 | DOI 10.1163/22141332-00502004

This is an open access article distributed under the terms of the prevailing CC-BY-NC license at the time of publication. 
illustrative purposes only. Besides, he will speak much less in his own name than report what he has heard in the public sphere or many times in private. Several of these reflections revealed the personal anguish he had to endure and to remedy it as best he could. Before sharing this information in these strictly confidential pages, he quite often, to the extent it was possible and almost beyond possible, defended the bishops whose behavior shocked people, whether rightly or wrongly.

It is of course understood that in speaking of "bishops," I am not speaking indiscriminately of all of them, without setting aside a number of exceptions. Far from it! On the other hand, we cannot ignore the many individual acts that prove that priests and pastors were among those whose attitudes were disappointing. However, their attitude, such as we are going to strive to describe it, seemed to be so generalized that one feels allowed to speak collectively.

In order to bring some order (of an entirely pragmatic nature) to the following, we will first provide the main criticisms directed towards French bishops, then we will analyze the main features of the distress that their attitude, over the course of these past four years, caused or worsened in the collective conscience.

Among the criticisms we plan to level against French bishops, there are some that come from a more or less deep misunderstanding of the Church's mission, as well as some confusion between the spiritual, the secular, and even political spheres. There would be no value in focusing on those. The more serious criticisms can be summed up in the five following charges:

1. Our bishops do not usually possess a very strong feeling of the independence of the Church. Their episcopal nature does not confer all the sacred honor one might hope for. This is why, although most of them are neither politicians nor social climbers, but sincerely pious and zealous prelates, they allow themselves to be easily led by the civil authorities, as soon as the latter puts pressure on them. When they learned that people would like them to be more independent, they thought they were being asked to be more oppositional, so difficult was it for them to imagine having a higher status (despite expressions such as the famous "loyalty without subjugation"). People only wanted them to act more like bishops. The fact is that many of them abdicated their spiritual authority, in practical terms, from the beginning of the Vichy regime (a fact based on a number of thoughtless acts they committed) and were no longer able to regain their independence without appearing to join the opposition.

It was this failing that caused many bishops to become entranced by the question of political power and of the "legitimacy" of Vichy; it was as if once this issue was decided, all other decisions were as well when it came to Vichy; as if the most legitimate and perfect government that might exist would 
not have left the spiritual responsibilities of the leaders of the Church intact. Numerous acts of servility arose from this: one bishop moved one of his priests who was guilty of having read a statement to a church group (written by cardinals and archbishops) that the prefect did not like; another forbade clergymen access to their own dioceses, without investigations or any sort of prior warning because of an absurd prefectural injunction; yet another accepting without uttering a word that legionnaires prevent one of his priests from teaching the catechism to a young Jewish man who had begun to prepare for baptism before the war etc., etc. So many letters and orders regarding wheat, metals, even objects of worship [...] extorted by civil authorities. (For the time being, we will not mention other more serious pronouncements, in response to the desires of the occupying power.) From this came all kinds of benedictions and ceremonies devoid of spiritual value and whose effects were disastrous. There were so many times when the bishops found themselves summoned rather than invited and where the Church was called upon in the most brazen way to cover for a regime. They were not free to let their voices be heard. Hence the monstrous principle of the submission of episcopal acts to state censorship was accepted obediently by almost all; a principle that was so well accepted that many bishops censured themselves in advance, so to speak. Moreover, nothing serious was ever attempted to disseminate even the weak statements of the assembly of cardinals and bishops that censorship had truncated. How wonderful would it have been if the firm attitude of Monsignor Bruno de Solages, a man of the Church who was not a bishop, had been adopted everywhere. ${ }^{1}$ Monsignor de Solages refused to allow a truncated doctrinal text of his to be published.

2. With the utmost care, established administrators ensured the many needs of those they were responsible for (often a heavy burden), while many of our bishops did not have the same degree of dedication to their evangelical mission. The "body" of the Church (the word "body" is not intended to be taken in a theological sense) led them to neglect its soul. In a sense, the very onerous means consumed them and caused them to forget the end result. They were very sensitive to anything that could hinder or on the contrary be beneficial to the institution of the established Church, always ready to defend goods that were threatened, or to receive favors and subsidies that the precarious situation of our schools and our work made desirable.

However, many bishops clearly did not see that their role went far beyond that. They did not understand that deep down, as they were called upon to "rule the Church of God"; they were supposed to be the voice of conscience and to plead for the God of justice. Hence the scandal of these past four years, where so often the Church appeared satisfied, while justice was violated

1 Bruno de Solages (1895-1983) was the rector of the Institut Catholique of Toulouse. 
everywhere, consciences tortured, and Christianity itself was trampled on. The Church of France appeared in the eyes of all to be benefiting heinously from a terrible situation. This interpretation was false, but it was inevitable. More particularly, the funds given to religious schools through a somewhat humiliating process, together with the outward prestige given to certain prelates (Cardinal Gerlier's trip to Spain, etc.) caused the crux of the matter to be forgotten. ${ }^{2}$ Someone said, on this subject, with undue bitterness, but not without some basis: "When Judas received his thirty pieces of silver, it was not impossible that he used them for charitable works, for example to open a school."

The attitude of the German episcopate was much more noble. They never thought that the submission owed to the state could keep them from raising their voice on any topic. They never used the concordat and the material advantages they had (despite many breaches) as an excuse to turn a blind eye to so many doctrines and acts that were contrary to their faith or simply to natural moral law! They never believed that they could remain silent, because their faithful would not suffer directly. They did not consider themselves merely as leaders and defenders of the faith, but as witnesses in God's realm and in that of God's justice.

Too many Catholics tend to believe that religious affairs are going well, when they themselves are not troubled, when their side is triumphant. Jews and "communists," for example, were hunted: was not that a double victory for them? It is sad to say that, instead of reminding them of the spirit of the Gospel, the attitude of the French episcopate only served to ground them in the sensual realm; not that they were truly encouraged by what was not said. It is a fact, for example, that in the majority of "Catholic" settings and even in a number of convents, the Church seemed deaf to even the most compelling and urgent calls for charity. The evidence of this is infinite.

3. If Catholic consciences were not at all enlightened, it is also because the entire body of the Church was suffering from serious failings from a doctrinal perspective. The shortcomings of episcopal letters, with few exceptions, are universally accepted. At a time when evil did not only arise out of unbridled zeal, but also was authorized by anti-Christian doctrines, at a troubled time when sensitive issues got entangled in the darkness, such shortcomings were particularly dangerous. We will only cite several examples herein.

Hitlerian propaganda unleashed an enormous number of works, journals, newspapers, brochures, publications, and lectures of all kinds on our country.

2 Pierre-Marie Gerlier (1880-1965) was cardinal archbishop of Lyon. For his efforts on behalf of Jews he was posthumously honored by Israel's Yad Vashem center as a Righteous among the Nations. 
Much of this propaganda, often in direct opposition to the faith, reached Catholics; part of it was directed towards them, and it was not unusual for it to be forced upon them. Sometimes it came from Catholics, priests even (I will cite, as an example the brochure of Fr. Gorce, published in 1941, In Order to Make the Best of Defeat) in a watered down form. ${ }^{3}$ However, to my knowledge there was never any singling out, forbidding or blame of any kind, nor any warning; the bishops for the most part, were not aware of the existence of these documents, or, if they were, did not recognize them as heinous or attributed little importance to them. Yet, their negative consequences were considerable. They contaminated many segments of the population, especially young people. There were renunciations of faith and much more frequently internal perversions of faith involved in maintaining "the practice (of religion)" [...].

There was no problem with sending Catholics, even priests, to be indoctrinated on the principles of the "national revolution," by a man who was otherwise held in high esteem and who was a follower and propagator of the ideas of Dr. Couchoud on the non-existence of Jesus. ${ }^{4}$ Numerous young leaders were led astray, persuaded that a promise made to a man was unwavering, that it bound their conscience, everywhere and for every purpose without their needing to take any moral principles into account. In order to become informed on the doctrine of the Church in relation to anti-Semitism, a certain bishop trusted the vile reports sent to him by the Bureau of Jewish Affairs [...]. By an unfortunate melding of the Church and the State, between faith and reason, between the "faithful" and the "citizen," some bishops showed themselves to be worried about the "new Protestantism," which, they said, was invading the Church. This was because Catholics refused to abdicate all rights of conscience to political power. A theologian, revered by all, the dean of one of our schools of theology, wrote a perfectly cautious and balanced deliberation on obligations in relation to the occupier and the Vichy government. The bishops treated it as if it were the ridiculous rough draft of a school child; they had taken their inspiration from the columns of Action française [...]. While Lesaunier's brochure was given the imprimatur without any trouble and without it ever being refuted, etc. ${ }^{5}$

It is a fact that the majority of bishops, with more or fewer rulings according to each case, adopted an attitude-be it in relation to the clandestine press,

3 De Lubac refers here very likely to Matthieu-Maxime Gorce (1898-1979).

4 Paul-Louis Couchoud (1879-1959) was a philosopher who was a passionate critic of the Catholic Church and who maintained that Jesus was not a historical figure.

5 Maurice Lesaunier (1883-1950), a priest of St. Sulpice who wrote in 1941 the brochure La conscience catholique en face du devoir civique actuel. 
French conscript labor in Germany, the "resistance," etc.- - that condemned Christians who were in Resistance, even if they did not take part in any violence, even if they were not involved in political opposition. Yet, the arguments used to justify this attitude, always came back to, in the end, the argument of "legitimacy." However, beyond the questionable applications that were made because of it, there was nothing traditional about the notion of legitimacy. The Church's doctrine when it came to authority has, as a basic notion, the idea of the common good; legitimacy being only a derivative idea, it presupposes a variety of relatively precise conditions, it is susceptible to change, it can be lost, etc. No one seemed to be aware of that.

Moreover, no one seemed to think that in many cases there were certain forms of devotion that a Catholic could not accept, even in regard to the most excellent of powers. Here we are alluding to the "cult of the Marshal" [Pétain, 1856-1951], which can seem especially ridiculous, but it was a way to introduce some of the most fearsome principles of Nazi doctrine and thought among us. Never (except for in the case of very few dioceses) did one hear protests against ceremonies, comments, and sacrilegious writings; never was there a warning against excesses, never a call for Christian dignity. On the contrary, the disequilibrium had penetrated into the sanctuary. Did not certain bishops swoon in admiration when they spoke of the Marshal saying that he was inspired? Another, did he not say that he had to keep himself from falling to his knees and asking for his benediction? Yet another, did he not effusively share the emotion he had felt when the Marshal told him: "They call the Virgin the queen of the martyrs, am I not the king of the martyrs?" Statements of this kind were countless. And did we not see a stained glass window installed representing the Marshal, in a well-known sanctuary, given by a member of his cabinet?

Better than personal motives, which would have been less honorable, this doctrinal impoverishment explains why the Church of France, overall, was silent when faced with the Nazi peril. Besides some deafening exceptions, this silence was in fact too real. It had incalculable consequences; all the more so under the terrible oppression that we were subjected to, the bishops were the only ones, who could have spoken, had they wanted to. Not only did they alone have authority as always, but also they alone could have made themselves heard. Among the consequences of their silence, we will only cite one particularly serious one. In many places, the clergy were exposed, defenseless to all the forces of propaganda and pressure that were foisted upon them. One cannot expect that all priests had an especially great ability to think critically, a deep understanding of worldwide problems or a keenly developed spirituality. For them, Hitlerism was a far off thing; for certain priests it was only a myth. They knew that they were on good terms with the masters of the moment. 
In their parishes, they themselves, were freed from a certain freemason, or an anticlerical teacher, they received a little money for their modest school, the brothers were wearing their garments again [...]. Why would they not have believed their regional version of the Croix (and almost all Catholic newspapers, alas, which were not only conformist, but "collaborationist"? One could read articles in them to the glory of Hitler, the leader of the crusade, etc.). The same could be said about Voix françaises (French voices), or a newspaper written especially for them, Cassocks of France, or the radio programs of a Creyssel ${ }^{6}$ or of a Philippe Henriot. ${ }^{7}$ That is how good and worthy priests, in more than one region, ended up declaring the wish that Hitler win and complaining about all resistance-sometimes, alas, they did even worse. There were incidents where blood was shed. These things would not have happened without the indifference of some bishops. Several of them have the blood of their own priests on their hands...

4. The situation would not have worsened at this point, if at least the Church in France had remained in closer contact with the life of the country. However, through their acquaintances, through ecclesiastical customs, through a series of prejudices and routines, the Church was too often disconnected from the people. If, following a lack of doctrine and independence, the bishops were willingly opportunistic (someone said of them, in perhaps somewhat of an exaggeration: "They spend their time calculating their chances"), they were guided by power, by the opinions of those in official positions or small groups rather than the broad currents of the national conscience. It was in this way that the division continued to widen between "collaborators" and "resistants," and while the great masses of the nation reserved their sympathies for the latter, the Church appeared to be on the side of the former. It can be said that overall the French people reacted in healthy ways; against most directives promoting Christian fidelity in order to join the ranks of the resistance; we slid further and further down the slopes of collaboration.

"What are people saying about me?," asked an archbishop to a jociste [member of Jeunesse ouvrière chrétienne (Christian youth workers)] about his parishioners.

"Monseigneur," he responded with total honesty, "they say that the day the wind shifts, you will be hanged."

"Ah!," said the archbishop struck speechless, "And you, what do you think?"

6 Paul Creyssel (1895-1975) was Vichy's secretary general for propaganda (December 1942March 1944).

7 Philippe Henriot (1889-1944), a journalist who became, in December 1943, the Vichy secretary of state for information. He was assassinated by the French Resistance. 
"Monseigneur, we don't want to be hung with you for that cause."

The archbishop forbade listening to the English radio, considering it a sin, while he presided over large lectures given by collaborators and banquets offered by the militia or the phalange... ${ }^{8}$ Others, happy with the government favors that they received, did not recognize the exploitation that occurred through their own compliance and the angry reactions they elicited in oppressed citizens. There was a time when in the news reels played in cinemas, between two announcements about a given policy, about an anti-Bolshevik group or an untruthful "report" shown before a racist film, the screen almost always projected images of cardinals' purple robes. The Church seemed to be surrounded by all that which was, for good reason, abhorred.

Yet, if no other consideration mattered to them, how would bishops have presided as they did over ceremonies such as the solemn funeral of Philippe Henriot or the services held to honor them, how would they have given the speeches that some of them did, if they had had any of the feelings generated by the national conscience held by most of the country? How would they have been able to maintain until the very end, as many did, their intransigence when it came to the advocacy of work in Germany and in their massive condemnation of the "resistance"? How account for their obstinate refusal (alas, how could one excuse it before God?), to allow a priest, even in passing, access to many young people who were often deprived of all moral support and who died, tortured by their assassins, with the awful thought, on top of everything, that the Church had rejected them?

5. The fifth failure is, like the first, of a more strictly ecclesiastic type. People must have noticed, on the part of French bishops over the course of these last few years, a weakening of their belief in the universality of the Church and in the unity of the episcopate. There was a renewal of interest in Gallicanism. ${ }^{9}$ The word is perhaps a bit strong, for something that has particularly negative implications. Yet, it is a fact that bishops were cut off from Rome for all intents and purposes, but most of them did not seem to care. Another power being closer, the followers of "papolatry" shifted to "Pétainolatry" without much discomfort. The encyclical Mit brennender Sorge (1937) was forgotten. It was thought to be completely natural that the Maison de la bonne presse published the volume of the documents of Pius XI [r.1922-39] that was supposed to contain it, without mentioning a word of it. A bishop declared that after having read that encyclical he came to the conclusion it was only an issue of religious politics, debated at that time between Pius XI and the Third Reich, and that we need not worry about it. As for the decree by the Holy See, addressing schools of theology on

8 Supporters of the Vichy regime.

9 View that state authority over Catholicism is comparable to the authority of the Vatican. 
the errors of racism, it was in fact a doctrinal document, but was not countersigned by the pope in person and was not worthy of our attention. Another bishop forbade a small newsletter called The Voice of the Vatican, which provided without additional commentary and with every possible attention to exactitude, the messages of Vatican Radio. Others had no difficulty sacrificing the very principle of Christian unionism, despite the formal and relentless directives from the Holy See on this subject, saying that they were outdated.

In a more general fashion, our bishops were mortified by the fact that the Cahiers du témoignage chrétien (Journal of Christian testimony), or other vehicles, made known to French Catholics the teachings of German, Belgian, or Dutch bishops. They seemed to have forgotten that the episcopate was unique, and that each bishop had the same responsibility, along with all his colleagues in communion with the Chair of Saint Peter in the universal Church. Some of them complained, contending that their faithful did not have the right to hear any other voice but theirs. Without going that far, many relied on the incontrovertible fact that the political situation was not the same in France as it was in other countries, in order to refuse to involve themselves in any sort of solidarity with their colleagues in the episcopate, when it came to spiritual resistance. In effect, one could observe a clear tendency towards considering their situation as analogous to civil servants.

It was not surprising that a similar mindset (resulting in a series of facts that we merely wanted to give a few examples of in writing, in the interest of representing rather than to provide information per se) created a deep discomfort among the most fervent French Catholics, attached as they were to Christ and his Church. Its cause was too serious and general for this discomfort to dissipate on its own. Unfortunately, one can fear that many of our bishops, even today, are not at all aware of it. That is a testimony to their good will and forthrightness. Yet, if no rather brutal fact succeeds in waking them to reality, there is no guarantee that they can supply the remedy.

One could say that the discomfort is doubled. There is, on the one hand, the national conscience and, on the other hand, and more deeply, their souls.

1. In the past, a "resistance" existed in the country that felt it was more than misunderstood, more than held separate from religious authority; it felt if not canonically, at least morally excommunicated. Most bishops, or a certain number of them, made statements to the contrary and had not ratified the short redemptive statement by the cardinals and archbishops regarding departures to Germany. Expressions of outrage rained down on "resistants" indiscriminately. Nowhere could they obtain access to priests, etc., even in passing. In different places, certain political prisoners (who asked for a trial and who were sometimes destined to be acquitted) were denied the sacraments as if they were notorious sinners; as if it were understood that their imprisonment 
demonstrated clearly that they had rebelled against the government, etc. Yet, today this "resistance" is in power and includes many very good Catholics. In the past, the official Church offered them none of the indulgences that they offered men who were decidedly much less Christian and who did not hesitate to intimidate it. These Catholics did feel bitter. Besides, the more devoted they were to the Church, the more they suffered by seeing it compromised, in a state of moral inferiority, in a country that relentlessly brings up everything that reminds it of domination by Hitlerian Germany and its partisans. They knew very well that the Church had not made a pact with Hitlerian Germany, but they could not be blind to the failings that we have described, that the Church seemed to be doing just that. They also knew that something very different was afoot than the sort of political fluctuations, of which history offers many examples. They had the feeling that if the Church did not have the courage to make certain gestures of renewal, it risked being lost in the eyes of the country, perhaps for a long time. They worried about witnessing, even for relatively subordinate roles, the same ecclesiastical figures, who were more or less known to have been "collaborators" in the recent past, and from whom it would be useless to expect the least bit of help for the spiritual renewal that was called for. They seem to continue to enjoy the confidence of the episcopate today.

On the other hand, it is true that most of the country is hardly interested in the issue, even though several bishops are very unpopular at this time. Should one be pleased with that? Perhaps, in a way. However, it is rather an appalling sign of the populace's great indifference, an indifference that comes fittingly from the fact that the episcopate no longer really matters in the eyes of the people. It had lost credibility because of an attitude without a measure of generosity. On top of this indifference, one must not ignore that an anticlerical attitude remains latent. It is part of our national tradition and it would be naive to believe it to be otherwise. Everything that has just taken place has fed it. Dossiers have been created in the shadows. If the Church does not take notice first, great campaigns can be unleashed, tomorrow or in the future, either in relation to the debate on schools or at election time.

2. On a deeper level, we have said, is a malaise of the soul. Because of all that has happened over the last four years, as abnormal as it might appear, it is merely the sign (more visible because the circumstances were more formidable) of a spiritual collapse of our Church in France. It is important not to hide this fact behind "well-meaning" apologetics. Without complete honesty, no improvement is possible.

Profound souls, which one must consider first, will not be fooled. In the past, these souls felt anguish perhaps above all for themselves. Today their anguish is above all in relation to the Church. It is impossible for us to linger much longer on a subject, which would require very sensitive analyses and lengthy 
reflection. We will only note, to conclude, three sets of regrettable facts, which could be verified and commented on, if one had the time, by providing very specific examples.

The elites of the group Action catholique were often discouraged. There were those who abandoned Church leaders, others who only held fast to them through self-denial; others who ordinarily would have become involved in Action catholique, turned away from it. This is because Action catholique, contrary to the reasons for its creation by Pius XI, was put under tighter and tighter supervision, under a hierarchy that seemed to be more and more powerless to provide the motivation necessary.

An incarnate Christianity has been mentioned quite a bit over these last few years. However, the true "incarnation" of Christianity consisted of, first and foremost, the tragic situation we found ourselves in, not failing to honor the overriding duties we were charged with: the duty to defend our Christianity against the brutal invasion of the pagan mindset; the duty to be charitable towards the persecuted. Yes, in response to this dual duty, according to the directives received from the hierarchy, Action catholique systematically refused it. Yet, at the same time, all its best elements spontaneously volunteered and many made the ultimate sacrifice. Such was, in sum, the conflict. I know everything that one could say to justify the wisdom of certain directives. Much prudence was essential. However, nothing should prevail against the logic of certain Christian imperatives. And could one maintain that only prudence according to that mindset would explain, for example, certain projects of a new stature for Action catholique in France, or certain directives given for the Bordeaux region, several weeks before the liberation? If the underlying causes remained and the conflict appeared to be alleviated inside Action catholique, it is because it was in fact stripped of its substance, no longer anything more than a weak society of emasculated Christians, as one of its leaders has said recently and who seemed to find this only natural $[\ldots]$.

Outside of the Church, there are currently many from the intellectual elite who are turning towards Christianity. The turmoil made them reflect. They seemed sensitive to great voices like those of Pius XI or Pius XII [r.1939-58]. Their contact, through clandestine activities and in prisons, with Christian resistants was for them an opportunity for the fruitful exchange of ideas. They admired the Gospel; they foresaw that the Church through the words of eternal life could hold the secret to secular life. These men were close to us. However, at the last minute, they hesitated. The current spectacle that the Church is offering does nothing to encourage them. They cannot take it seriously. What they criticize the Church for is precisely the lack of deep faith, a lack of confidence in the power of the Gospel. This is the equivalent of not being sufficiently aware of one's own resources [...]. 
Finally, it must be noted-because even though it does not appear in the light of day to be mass phenomena, this fact is not exceptional-the interest in Protestantism by a certain number of Catholics, both men and women. The reason for this is that its doctrinal weaknesses and inconsistencies notwithstanding, Protestantism seems to have, in their eyes at the present time, a strength of faith, a purity of Christian spirit, a spiritual elevation, a care for the things of God and of the soul, a noble independence, that one no longer encounters to the same degree in Catholicism.

As unheard of as it is on the surface, this fact is serious and it would make no sense to want to remedy it through numerous supervisory directives. An anecdote in relation to this is meaningful and its authenticity has been confirmed for us. It is sufficient, moreover, for our purposes in that it sums up a certain number of ideas disseminated in these pages. A pastor went to visit a bishop, to take care of a matter that required their shared participation. When it was time to leave, wanting to end on a fraternal note:

"Excellency," he said, "Protestants and Catholics have many matters of disagreement; there are still between us many differences in doctrine; but it is a comfort to think that all the same, there is someone in whom we can be united [...]." "Yes, Pastor," interrupted the bishop, shaking his hand effusively, "yes, the Marshal [Pétain]!"

The misunderstanding was innocent. This is sad.

We know that everything discussed above is one-sided. We want this essay to be strictly confidential. We can insure that we wrote it dispassionately. We know that it is not a question of accusing men (about each of those who showed themselves to be the most inadequate, one could likely say many complimentary things), but in order to take note of a social phenomenon. This phenomenon, we have called it a certain spiritual collapse of the Church in France.

It has its recompense: the rise that could be seen over the last twenty years or so of a lucid and rigorous elite. That is what has made the conflict more intense. It is also what allows for hope. However, it is crucial that this elite not have an ever increasing feeling of being misunderstood, or feeling the need to resign itself to living in the margins of society. As such, it would no longer be bathed in the great current of Catholic life. We know that we all need our bishops. We are their sons and we love them. We cannot live without them. If we have suffered because of them, let them accept to suffer for us for a moment, so that they, with our help and we under their guidance, may work together, with renewed energy, under the Reign of Christ in tomorrow's France. 